\title{
ANALISIS APLIKASI MODEL NERACA PEMBAYARAN DAN MODEL MONETER TERHADAP NILAI TUKAR RUPIAH/ DOLAR, PERIODE 1980.1 - 2000.4
}

\author{
Didi Nuryadin dan DR. Bagus Santoso, M.Soc.Sc ${ }^{1}$
}

\begin{abstract}
This paper is aimed to analyze variables determines the exchange rate of rupiah. Using exchange rate model (balance of payment and monetary model) developed by Fullerton, Hattori and Calderon (2001) we incorporate two additional variables namely policy variable and crises variable.

We apply unit root test to observe the existence of structural break during observed period. Prior the implementation of Engel-Granger Error Correction Model, we test whether our variables in equation are cointegrated. Following Hendry's general to specific modeling procedure, we get two simple models namely balance of payment and monetary model.

Our result shows all explanatory variables significantly determine exchange rate in both models. However international reserve and national income has opposite sign before and during the crisis. Devaluation which is captured by dummy variable has positive impact (depreciates) exchange rate as well as crisis dummy variable. We also note that the speed of adjustment in balance of payment model, $17.51 \%$ is greater than in monetary model, $12.47 \%$.
\end{abstract}

Keywords: Exchange rate, balance of payment, structural break, Error Correction Model JEL: C32, F31, F41.

\footnotetext{
1 Didi Nuryadin adalah lulusan Program Master PPS Universitas Gadjah Mada. DR Bagus Santoso M,Soc. Sc. adalah staf pengajar pada PPS Universitas Gadjah Mada, didi_nuryadin@yahoo.co.in
} 


\section{PENDAHULUAN}

Setelah sistem Bretton Woods runtuh pada tahun 1973, beberapa negara terutama negara-negara industri memberlakukan sistem nilai tukar mengambang (floating exchange rate). Dalam merespon situasi tersebut, pendekatan moneter terhadap nilai tukar mulai diperkenalkan. Pendekatan moneter terhadap faktor-faktor yang mempengaruhi nilai tukar muncul menjadi teori yang sangat dominan pada awal 1970-an dan sekaligus sebagai salah satu paradigma dalam nilai tukar.

Dalam pandangan moneter atau aset, nilai tukar akan cenderung menuju ke keseimbangan internasional yang ditentukan dari interaksi permintaan dan penawaran uang. Asumsi dari pendekatan ini adalah modal dapat bergerak lintas negara secara bebas dan kondisi paritas suku bunga berlaku.

Keseimbangan nilai tukar jangka pendek seringkali terdeviasi dari keseimbangan nilai tukar jangka panjang karena sifat nilai tukar yang sangat fluktuatif (volatile) sehingga asumsi paritas daya beli (PPP) tidak berlaku dalam jangka pendek. Hal ini didukung oleh penelitian yang dilakukan Lee (1975) dan Manzur (1993), yang menemukan bahwa PPP berlaku dalam jangka panjang (Visser Hans, 2000).

Perubahan nilai tukar akan mencerminkan perbedaan tingkat inflasi. Jika PPP berlaku, maka nilai tukar riil (real exchange rate) akan konstan sehingga fluktuasi nilai tukar riil akan mencerminkan deviasi dari PPP. Dengan demikian penguarh shock atas nilai tukar akan semakin mengecil dan akhirnya kembali pada tingkat keseimbangan sebelumnya.

Berbagai bukti empiris mendukung keberadaan beberapa bentuk hubungan jangka panjang antara harga relatif dengan nilai tukar, namun tidak selalu mendukung dalil PPP. Implikasinya model yang digunakan untuk menjelaskan perilaku nilai tukar harus dalam bentuk dinamis. Kim dan Mo (1995) menggunakan teknik multivariate cointegration untuk menghasilkan prediksi jangka panjang dari nilai tukar dolar AS/ Mark Jerman (DM). Spesifikasi model koreksi kesalahan yang dipergunakan, mendukung PPP.

Hasil yang senada dilakukan oleh Thomas M. Fullerton, Jr. Miwa Hattori dan Cuauhtemoc Calderon (2001). Peneliti ini juga mempergunakan spesifikasi model dinamis koreksi kesalahan (error correction) pada nilai tukar nominal peso/ dolar AS yang diaplikasikan pada model neraca pembayaran dan moneter.

Berdasarkan uraian di atas maka kebutuhan akan keseimbangan nilai tukar dalam jangka pendek maupun jangka panjang menjadi sesuatu yang penting dalam perekonomian, mengingat perannya dalam mentransmisikan kebijakan moneter. Oleh karena itu, bagaimana 
pengaruh variabel-variabel fundamental ekonomi dalam mempengaruhi nilai tukar menjadi permasalahan utama dalam tulisan ini.

\section{STUDI PUSTAKA}

Tucker, et.al (1991) menjelaskan variasi pergerakan nilai tukar menggunakan model moneter versi ketegaran harga (sticky price) dengan asumsi bahwa penawaran uang di masing-masing negara adalah endogen dan kondisi purchasing power parity (PPP) hanya berlaku dalam jangka panjang. Tucker menemukan bahwa koefisien jumlah uang beredar dan harapan inflasi bertanda positif, sedangkan pendapatan riil bertanda negatif. Lebih lanjut koefisien suku bunga dapat bertanda positif maupun negatif karena tiga komponen yang berbeda dan mencerminkan berbagai cara bagaimana perbedaan suku bunga mempengaruhi pergerakan nilai tukar valuta asing.

Berkenaan dengan pemenuhan komponen non-random pada perilaku nilai tukar, MacDonald (1995) berpendapat bahwa secara substansial bukti-bukti empiris mendukung keberadaan beberapa bentuk hubungan dalam jangka panjang antara harga relatif dengan nilai tukar. Seringkali tandanya tidak sesuai dengan dalil PPP dan implikasinya keberhasilan tergantung dari upaya membentuk model dengan konteks dinamis. Lebih lanjut dikemukakan model dinamis dapat diterapkan untuk menjelaskan perilaku nilai tukar. Dengan cara yang sama, McNown dan Wallace (1994) menemukan bukti secara terpisah yang mendukung dalil PPP bagi negara-negara yang mengalami inflasi tinggi. Model mengkombinasikan pendekatan moneter dan karakteristik PPP sehingga dapat mencakup secara spesifik nilai tukar negaranegara Amerika Latin dengan karakteristik tingginya pertumbuhan relatif terhadap Amerika.

MacDonald dan Taylor (1992) menyatakan bila harga-harga barang amat fleksibel maka doktrin PPP akan berlaku dalam jangka pendek. Dengan mempergunakan persamaan dasar model moneter-harga fleksibel keduanya menemukan bahwa penawaran uang domestik relatif terhadap stok uang luar negeri berkorelasi positif dengan nilai tukar mata uang domestik yang berarti setiap kenaikan penawaran uang domestik relatif terhadap stok uang luar negeri akan menyebabkan mata uang domestiak terapresiasi. Variabel pendapatan riil domestik berkorelasi positif dengan nilai mata uang domestik yang berarti peningkatan pendapatan riil akan mengakibatkan apresiasi mata uang domestik. Terhadap variable tingkat suku bunga, McDonald dan Taylor menemukan bahwa semakin tinggi perbedaan suku bunga, semakin terdepresiasi mata uang domestik.

Implikasi dari pendekatan aset adalah bahwa nilai tukar akan lebih banyak dipengaruhi oleh lebih banyak variabel dibanding hanya harga barang-barang (Melvin, 1995). Hal ini 
sesuai dengan kenyataan (dalam Tabel 1.1) memperlihatkan standar deviasi dari persentase perubahan harga dan nilai tukar tiga negara. Melvin (1995) mengemukakan kurs spot empat negara termasuk Indonesia lebih volatile dibanding tingkat harga. Perbandingan tingkat harga dengan nilai tukar, ditemukan bahwa tingkat volatilitas nilai tukar 3,2 sampai 11 kali tingkat volatilitas harga. Hal ini konsisten dengan kenyataan bahwa respon tingkat nilai tukar terhadap perubahan kondisi pasar aset finansial, akan tetapi tidak sesederhana reaksi terhadap perubahan dalam perdagangan barang internasional.

\begin{tabular}{l|c|c|}
\multicolumn{2}{c}{ Tabel 1.1 } \\
\multicolumn{2}{c|}{ Standar Deviations of Prices and Exchange Rates } \\
\hline \multicolumn{1}{|c|}{ Country } & Price & Exchange Rate \\
France & .003 & .029 \\
Germany & .003 & .033 \\
United Kingdom & .009 & .029 \\
Indonesia & .032 & .125 \\
Sumber: M.Melvin,"International Money and Finance", HarperCollins, 1995. &
\end{tabular}

Model nilai tukar modern memperhatikan jenis pasar pasar aset finansial dengan asumsi mobilitas kapital sempurna. Mobilitas kapital sempurna berarti bahwa kapital akan mengalir bebas di antara negara-negara karena tidak terdapat biaya transaksi yang signifikan atau adanya kontrol kapital.

\section{METODOLOGI}

Mengacu pada model yang dikemukakan oleh Thomas M.Fullerton, Jr. Miwa Hattori dan Cuauhtemoc Calderon (2001), penelitian ini mengadaptasi model yang telah ada untuk mengamati faktor-faktor yang mempengaruhi nilai tukar di Indonesia. Model tersebut dinyatakan dalam bentuk logaritma sebagai berikut:

1. Model Neraca Pembayaran

$$
\begin{aligned}
& \mathrm{s}_{\mathrm{t}}=\mathrm{a}_{0}+\mathrm{a}_{1}\left(\mathrm{cpi}-\mathrm{cpi}^{*}\right)_{\mathrm{t}}+\mathrm{a}_{2}\left(\mathrm{r}-\mathrm{r}^{*}\right)_{\mathrm{t}}+\mathrm{a}_{3} \mathrm{TR}_{\mathrm{t}}+\mathrm{U}_{\mathrm{t}} \\
& \text { catatan: tanda( }\left(^{*}\right) \text { untuk variabel luar negeri (foreign) }
\end{aligned}
$$

$a_{1}, a_{2}$, dan $a_{3}$ adalah koefisien yang merepresentasikan respon terhadap nilai tukar nominal dari perbedaan harga pada dua negara, perbedaan tingkat suku bunga, dan pergerakan cadangan internasional domestik. Koefisien yang diharapkan dari persamaan (1.1) adalah $a_{1}>0, a_{2}<0$, dan $a_{3}<0$. 
2. Model Moneter

$$
\begin{aligned}
\mathrm{s}_{\mathrm{t}}= & \mathrm{f}_{0}+\mathrm{f}_{1}\left(\mathrm{cpi}-\mathrm{cpi} i^{*}\right)_{t}+\mathrm{f}_{2}\left(\mathrm{r}-\mathrm{r}^{*}\right)_{t}+\mathrm{f}_{3}\left(\mathrm{~m}_{2}-\mathrm{m}_{2}^{*}\right)_{t}+ \\
& \mathrm{f}_{4}(\mathrm{gdp}-\mathrm{gdp})_{t}+\mathrm{W}
\end{aligned}
$$

model moneter menekankan peranan keseimbangan permintaan dan penawaran uang dalam menentukan nilai tukar. Tanda koefisien yang diharapkan dari persamaan (1.2) adalah $\mathrm{f}_{1}>0, \mathrm{f}_{3}=1$, dan $\mathrm{f}_{4}<0$. Tanda untuk $\mathrm{f}_{2}$ tidak jelas. Peningkatan dalam tingkat suku bunga domestik secara umum mengakibatkan apresiasi mata uang, implikasinya tanda untuk $\mathrm{f}_{2}<0$. Dornbusch (1976) pada model ketegaran harga (sticky price model), mengemukakan bahwa $\mathrm{f}_{1}>0$ dan $\mathrm{f}_{2}=0$. Alternatif model akan memberi banyak kemungkinan yang dapat terjadi. Kim dan Mo (1995) membangun bentuk harga fleksibel (flexible price) dengan $\mathrm{f}_{2}>0$. Persamaan (2) secara spesifik menggambarkan keseimbangan jangka panjang rupiah/dollar. Koefisien $f_{3}$ dan $f_{4}$ mewakili respon pada nilai tukar nominal terhadap perubahan jumlah uang beredar dan pendapatan riil.

Alat analisis yang digunakan dalam penelitian ini adalah Engle-Granger Error Correction Model (EG-ECM). Adapun pertimbangan penggunaan alat analisis tersebut karena model koreksi kesalahan mampu meliputi banyak variabel dalam menganalisis fenomena ekonorni jangka pendek maupun jangka panjang, serta mampu mengkaji konsistensi model empiris dengan teori ekonomi. Selain itu, model ini mampu mencari pemecahan terhadap persoalan variabel runtun waktu (time series) yang tidak stasioner dan regresi lancung (spurious regression) dalam ekonometri (Insukindro, 1999).

Tahap pertama, mengestimasi parameter jangka panjang. Hal ini dilakukan dengan melakukan regresi persamaan kointegrasi $y_{t}=\beta_{0}+\beta_{1} x_{t}$. Jika $\mathrm{y}_{\mathrm{t}}$, dan $\mathrm{x}_{\mathrm{t}}$ terkointegrasi maka koefisien parameter jangka panjang $\boldsymbol{\beta}_{0}$ dan $\boldsymbol{\beta}_{1}$ akan konsisten.

Tahap kedua adalah melakukan estimasi terhadap persamaan $\Delta y_{t}=\operatorname{lagged}(\Delta y, \Delta x)-\lambda u_{t-1}+\varepsilon_{t}$. Panjang lag yang digunakan dalam estimasi jangka pendek ditentukan dengan uji $F$ (general F-testing). Kemudian melalui metode general-tospecific yang dikembangkan oleh Hendry (Hendry's General-to-Specific Modeling (HGSM) strategy), dilakukan reduksi mulai dari lag terpanjang sehingga didapatkan hasil estimasi yang paling sederhana (parsimonious regression). Pada tahap ini estimasi dan parameter jangka pendek lainnya dapat diperoleh. Estimasi jangka pendek diperoleh dari persamaan ECM Engle-Granger sebagai berikut (Harris, 1995; Gujarati, 2000; Enders, 1995): 
Model neraca pembayaran:

$$
\begin{aligned}
\Delta L K U R S=\psi_{0} & +\sum_{j=1}^{N} \alpha_{i j} \Delta L K U R S_{t-j}+\sum_{j=0}^{n} \beta_{i j} \Delta c p i_{t-j}+\sum_{j=0}^{n} \gamma_{i j} \Delta R_{t-j}+\sum_{j=0}^{n} \delta_{i j} \Delta L T R_{t-j}+d u m k 1 \\
& + \text { dumk } 2+\lambda u_{t-1}
\end{aligned}
$$

Model moneter:

$$
\begin{aligned}
\Delta L K U R S=\psi_{0} & +\sum_{j=1}^{n} \alpha_{i j} \Delta L K U R S_{t-j}+\sum_{j=0}^{n} \beta_{i j} \Delta c p i_{t-j}+\sum_{j=0}^{n} \gamma_{i j} \Delta R_{t-j}+\sum_{j=0}^{n} \Delta \delta L M 2_{t-j}+\sum_{j=0}^{n} \varphi \Delta L G D P_{t-j} \\
& + \text { dumk } 1+d u m k 2++\lambda u_{t-1}
\end{aligned}
$$

\section{HASIL DAN PEMBAHASAN}

\section{IV.1. Uji Akar Unit dan Derajat Integrasi}

Pada Tabel 1.2 dan 1.3 secara umum variabel-variabel dalam model dapat dikatakan tidak stasioner pada level atau I(0) baik melalui uji ADF maupun Philips-Perron. Namun demikian berdasarkan uji ADF variabel tingkat suku bunga $(R)$ telah stasioner pada level dengan tingkat signifikansi 10 persen, meskipun hal tersebut tidak didukung oleh uji PhilipsPerron. Oleh karena itu kurang meyakinkan untuk menyatakan bahwa variabel tersebut telah stasioner pada derajat nol. Kemudian uji akar-akar unit dilanjutkan dengan uji derajat integrasi untuk mengetahui pada derajat integrasi keberapa variabel-variabel tersebut akan stasioner. Hasil uji akar-akar unit pada derajat integrasi pertama (first-difference) selanjutnya menunjukkan bahwa seluruh variabel telah stasioner pada derajat integrasi pertama atau pada I(1). 


\section{Tabel 1.2}

Uji Akar-akar unit dan Derajat Integrasi (DF dan ADF-test)

\begin{tabular}{|c|c|c|c|c|c|c|c|c|}
\hline \multicolumn{2}{|c|}{ Variable } & \multicolumn{4}{|c|}{ Level } & \multicolumn{3}{|c|}{ Fisrt Differences } \\
\hline \multicolumn{9}{|c|}{ Dickey-Fuller test } \\
\hline & \multirow[t]{2}{*}{ Lag } & \multicolumn{3}{|c|}{ ADF test } & \multirow[t]{2}{*}{ Lag } & \multicolumn{3}{|c|}{ ADF test } \\
\hline & & $\tau_{t}$ & $\tau_{\mu}$ & $\tau$ & & $\tau_{t}$ & $\tau_{\mu}$ & $\tau$ \\
\hline KURS & 0 & -1.7382 & 0.0643 & 2.3637 & - & - & - & - \\
\hline CPI & 0 & -0.3102 & 1.9834 & -0.1024 & - & - & - & - \\
\hline $\mathrm{R}$ & 0 & -1.7470 & -2.0480 & -1.2019 & - & - & - & - \\
\hline TR & 0 & -2.0777 & 0.3739 & 2.8933 & - & - & - & - \\
\hline M2 & 0 & -1.5873 & -1.5306 & -0.8751 & - & - & - & - \\
\hline GDP & 0 & -2.0756 & -1.7522 & 0.3701 & - & - & - & - \\
\hline \multicolumn{9}{|c|}{ Lag-length set by AIC minimum } \\
\hline KURS & 3 & -1.9196 & -0.1002 & 2.1410 & 2 & $-6.126^{\star * \star}$ & $-6.119^{* * *}$ & $-5.592^{* * *}$ \\
\hline CPI & 1 & -1.8370 & 0.3080 & -0.6627 & 4 & $-4.596^{* * *}$ & $-4.165^{* * *}$ & $-3.153^{* * *}$ \\
\hline $\mathrm{R}$ & 3 & $-3.292^{*}$ & $-2.862^{*}$ & -1.6063 & 2 & $-5.255^{\star * *}$ & $-5.132^{* * *}$ & $-5.134^{* * *}$ \\
\hline TR & 1 & -2.994 & -0.381 & 1.081 & 1 & $-6.252^{* * *}$ & $-6.190^{* * *}$ & $-6.076^{* * *}$ \\
\hline M2 & 2 & -2.4612 & 0.4579 & 4.286 & 1 & $-6.405^{* * *}$ & $-6.385^{* * *}$ & $-3.691^{* * *}$ \\
\hline GDP & 5 & -0.9883 & 2.1116 & 4.0933 & 4 & $-4.718^{* * *}$ & $-3.988^{* *}$ & -1.956 \\
\hline \multicolumn{9}{|c|}{ Lag-length set by $\max R^{2}$} \\
\hline KURS & 3 & -1.9196 & -0.1002 & 2.1410 & 2 & $-6.126^{* * *}$ & $-6.119^{* * *}$ & $-5.592^{* * *}$ \\
\hline CPI & 5 & -0.4605 & 1.4890 & -0.4629 & 4 & $-4.596^{* * *}$ & $-4.165^{\star * *}$ & $-3.153^{* * *}$ \\
\hline $\mathrm{R}$ & 8 & -2.3101 & -2.1010 & -0.2504 & 7 & $-4.440^{* * *}$ & $-4.381^{* * *}$ & $-4.086^{* * *}$ \\
\hline TR & 4 & -3.6183 & -0.2504 & 1.0648 & 3 & $-4.588^{* * *}$ & $-4.470^{* * *}$ & $-4.344^{* * *}$ \\
\hline LM2 & 5 & -2.7564 & 0.0797 & 1.9611 & 1 & $-6.405^{* * *}$ & $-6.385^{* * *}$ & $-3.691^{* * *}$ \\
\hline GDP & 5 & -0.9883 & 2.1116 & 4.0933 & 4 & $-4.718^{\star * *}$ & $-3.988^{* * *}$ & -1.956 \\
\hline \multicolumn{9}{|c|}{ Lag-length set by $l_{12}=\operatorname{int}\left\{2(T / 100)^{1 / 4}\right\}$} \\
\hline KURS & 11 & -1.8473 & 0.2949 & 2.0568 & 11 & -2.6858 & -2.6101 & -1.6183 \\
\hline CPI & 11 & 1.6121 & 2.1527 & -0.3565 & 11 & -1.7571 & -0.8128 & 0.1022 \\
\hline $\mathrm{R}$ & 11 & -2.5220 & -2.2649 & -0.3918 & 11 & -2.7725 & -2.6640 & -2.4544 \\
\hline TR & 11 & -2.5925 & 0.4669 & 2.7002 & 11 & $-5.180^{* * *}$ & $-5.778^{* * *}$ & $-3.246^{* * *}$ \\
\hline M2 & 11 & -2.0688 & 0.3852 & 1.0039 & 11 & -2.5419 & -2.7077 & -0.8151 \\
\hline GDP & 11 & -0.3601 & 2.0057 & 2.7156 & 11 & -3.3033 & -1.3393 & -0.2957 \\
\hline
\end{tabular}

Keterangan: ${ }^{* * *},{ }^{* *}$, dan * masing-masing menunjukkan signifikansi pada tingkat $1 \%, 5 \%$ dan $10 \%$ (McKinnon critical value). 


\begin{tabular}{|c|c|c|c|c|c|c|c|c|}
\hline \multicolumn{9}{|c|}{$\begin{array}{c}\text { Tabel } 1.3 \\
\text { Uji Akar-akar unit dan Derajat Integ }\end{array}$} \\
\hline \multicolumn{2}{|c|}{ Variable } & \multicolumn{4}{|c|}{ Level } & \multicolumn{3}{|c|}{ Fisrt Differences } \\
\hline \multicolumn{9}{|c|}{ Truncation lag=0 } \\
\hline & \multirow[t]{2}{*}{ Lag } & \multicolumn{3}{|c|}{ PP test } & \multirow[t]{2}{*}{ Lag } & \multicolumn{3}{|c|}{ PP test } \\
\hline & & $\tau_{t}$ & $\tau_{\mu}$ & $\tau$ & & $\tau_{t}$ & $\tau_{\mu}$ & $\tau$ \\
\hline KURS & 0 & -1.7381 & 0.0643 & 2.3636 & 0 & $-6.939^{* * *}$ & $-6.944^{* * *}$ & $-6.622^{* * *}$ \\
\hline CPI & 0 & -0.3102 & 1.9834 & -0.1024 & 0 & $-4.423^{* * *}$ & $-4.281^{* * *}$ & $-3.752^{* * *}$ \\
\hline $\mathrm{R}$ & 0 & -1.7470 & -2.0480 & -1.2019 & 0 & $-5.562^{* * *}$ & $-5.575^{* * *}$ & $-5.606^{* * *}$ \\
\hline TR & 0 & -2.3305 & -0.4382 & 1.4421 & 0 & $-8.206^{* * *}$ & $-8.173^{* * *}$ & $-8.097^{* * *}$ \\
\hline M2 & 0 & -2.0688 & 0.0494 & 7.1195 & 0 & $-9.497^{* * *}$ & $-9.531^{* * *}$ & $-6.058^{* * *}$ \\
\hline GDP & 0 & -0.5913 & 1.4574 & 8.6471 & 0 & $-7.608^{* * *}$ & $-7.336^{* * *}$ & $-4.865^{* * *}$ \\
\hline \multicolumn{9}{|c|}{ Truncation lag=3 } \\
\hline KURS & 3 & -2.2124 & -0.2148 & 1.9574 & 3 & $-6.940^{* * *}$ & $-6.947^{* * *}$ & $-6.653^{* * *}$ \\
\hline CPI & 3 & -1.0705 & 1.0136 & -0.4784 & 3 & $-4.519^{* * *}$ & $-4.373^{* * *}$ & $-3.798^{* * *}$ \\
\hline $\mathrm{R}$ & 3 & -2.5763 & -2.4044 & -1.5663 & 3 & $-5.584^{* * *}$ & $-5.600^{* * *}$ & $-5.631^{\text {***}}$ \\
\hline TR & 3 & -2.4761 & -0.5320 & 1.3532 & 3 & $-8.198^{* * *}$ & $-8.178^{* * *}$ & $-8.111^{* * *}$ \\
\hline M2 & 3 & -2.0746 & 0.0699 & 6.9069 & 3 & $-9.504^{* * *}$ & $-9.534^{* * *}$ & $-6.153^{* * *}$ \\
\hline GDP & 3 & -0.9159 & 1.1850 & 7.4274 & 3 & $-7.620^{\star * *}$ & $-7.398^{* * *}$ & $-4.871^{* * *}$ \\
\hline
\end{tabular}

Keterangan: ${ }^{* *},{ }^{* *}$, dan * masing-masing menunjukkan signifikansi pada tingkat $1 \%, 5 \%$ dan $10 \%$.

\section{IV.2. Uji Akar-akar unit dengan Structural Breaks}

\section{Tabel 1.4}

Recursive, rolling and sequential augmented Dickey-Fuller test of unit roots

\begin{tabular}{|c|c|c|c|c|c|c|}
\hline \multirow{2}{*}{ Variable } & \multicolumn{3}{|c|}{ Recursive } & \multicolumn{3}{|c|}{ Rolling } \\
\hline & $(k / \mathrm{T})$ & $\tau_{\tau}$ & $\min \tau_{\tau}$ & $(k / \mathrm{T})$ & $\tau_{\tau}$ & $\min \tau_{\tau}$ \\
\hline KURS & 0.25 & -1.84526 & -2.75023 & 0.297 & -2.15992 & -3.19645 \\
\hline CPI & 0.25 & -1.59590 & -2.65059 & 0.309 & -1.48813 & $-5.2267^{* \star}$ \\
\hline $\mathrm{R}$ & 0.25 & -2.38851 & -3.70324 & 0.297 & -2.07001 & -3.44335 \\
\hline TR & 0.25 & -1.92519 & -3.57730 & 0.309 & -1.45081 & -3.02359 \\
\hline M2 & 0.25 & -1.44672 & $-4.0789^{* *}$ & 0.309 & -0.65327 & -3.92241 \\
\hline GDP & 0.25 & -2.34460 & -3.30887 & 0.309 & -2.29463 & -2.50496 \\
\hline \multirow{2}{*}{ Variable } & \multicolumn{3}{|c|}{ Recursive } & \multicolumn{3}{|c|}{ Rolling } \\
\hline & $(k / \mathrm{T})$ & $\tau_{\tau}$ & $\min \tau_{\tau}$ & $(k / \mathrm{T})$ & $\tau_{\tau}$ & $\min \tau_{\tau}$ \\
\hline KURS & 0.142 & -2.96049 & 3.26199 & 0.142 & -1.90457 & 4.15694 \\
\hline CPI & 0.142 & -1.04558 & 11.25970 & 0.142 & -0.49838 & 9.05852 \\
\hline $\mathrm{R}$ & 0.142 & -4.02045 & 10.03647 & 0.142 & -3.99719 & 8.46772 \\
\hline TR & 0.142 & -2.95104 & 2.264647 & 0.142 & $-4.5911^{* *}$ & 4.11935 \\
\hline M2 & 0.142 & -2.22868 & 1.529522 & 0.142 & -3.053204 & 2.53974 \\
\hline GDP & 0.142 & -1.47502 & 1.969016 & 0.142 & -1.609716 & 2.68881 \\
\hline
\end{tabular}

**, * Reject the nol at 5\% and 10\% significance level (Critical value Banerjee, Lumsdaine and Stock). 
Pada Tabel 1.4, dapat dilihat bahwa terdapat sedikit bukti untuk menolak hipotesis nol tentang keberadaan akar unit. Pada metode recursive memperlihatkan bahwa terdapat variabel yang menunjukkan bukti adanya break yakni pada variabel selisih jumlah uang beredar (M2), terjadi pada tahun 1990 kuartal tiga. Metode rolling menghasilkan informasi yang berbeda, yakni break terjadi pada variabel perbedaan tingkat harga (CPI) yang diduga terjadi pada tahun 1986 kuartal dua. Metode sequence F-statistik yang dihitung dengan metode mean shift dan trend shift menginformasikan adanya break pada variabel total reserve (TR).

\section{IV.3. Uji Kointegrasi}

\section{Uji Kointegrasi ADF dan Philips-Perron}

Sejalan dengan konsep yang dikembangkan oleh Engle dan Granger (1987), dilakukan uji kointegrasi pada model statik untuk menjelaskan hubungan jangka panjang variabel yang diamati. Hasilnya dapat dilihat pada Tabel 1.7, dapat disimpulkan bahwa residual regresi kointegrasi adalah stasioner, $I(0)$, sehingga variabel-variabel dalam model dapat dikatakan berkointegrasi atau mempunyai konsistensi hubungan keseimbangan jangka panjang.

\begin{tabular}{|c|c|c|c|c|c|c|}
\hline & Hasil E & $\begin{array}{r}\text { Tab } \\
\text { asi Uji r }\end{array}$ & $\begin{array}{l}1.7 \\
\text { ntegras }\end{array}$ & F \& PP & & \\
\hline Model Dasar & Nilai ADF & \multicolumn{2}{|c|}{ Critical Value } & \multirow{2}{*}{$\begin{array}{l}\text { Nilai PP } \\
-4.190299^{* * *}\end{array}$} & \multicolumn{2}{|c|}{$\begin{array}{l}\text { Mc Kinnon } \\
\text { Critical Value }\end{array}$} \\
\hline \multirow[t]{3}{*}{$\mathrm{kurs}=\mathrm{f}(\mathrm{cpi}, \mathrm{r}, \mathrm{tr})$} & \multirow[t]{3}{*}{$-5.299876^{* * *}$} & $C(1 \%)$ & -4.90191 & & $1 \%$ & -4.0713 \\
\hline & & $C(5 \%)$ & -4.26788 & & $5 \%$ & -3.4639 \\
\hline & & $C(10 \%)$ & -3.94717 & & $10 \%$ & -1.1581 \\
\hline \multirow[t]{3}{*}{ kurs $=f(c p i, r, m 2, g d p)$} & \multirow[t]{3}{*}{$-4.892428^{* *}$} & $\mathrm{C}(1 \%)$ & -5.25864 & \multirow[t]{3}{*}{$-3.912748^{* *}$} & $1 \%$ & -4.0713 \\
\hline & & $C(5 \%)$ & -4.61371 & & $5 \%$ & -3.4639 \\
\hline & & $C(10 \%)$ & -4.28850 & & $10 \%$ & -3.1581 \\
\hline
\end{tabular}

Keterangan: critical value dihitung dengan response surfaces

\section{Uji Kointegrasi Johansen}

Hasil pengujian kointegrasi Johansen terhadap variabel-variabel dari kedua model dilakukan dengan asumsi terdapat komponen deterministik trend pada data level. Lihat Tabel 1.8 dan 1.9 . 


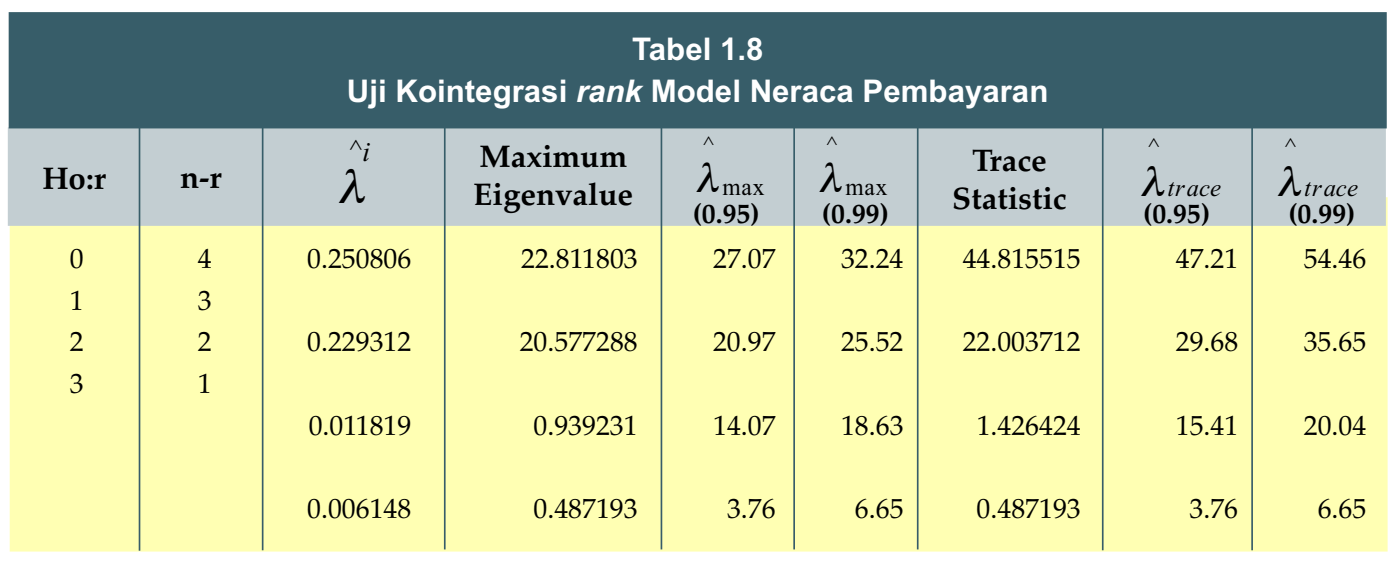

Keterangan: Test assumption: Linier deterministic trend in the data

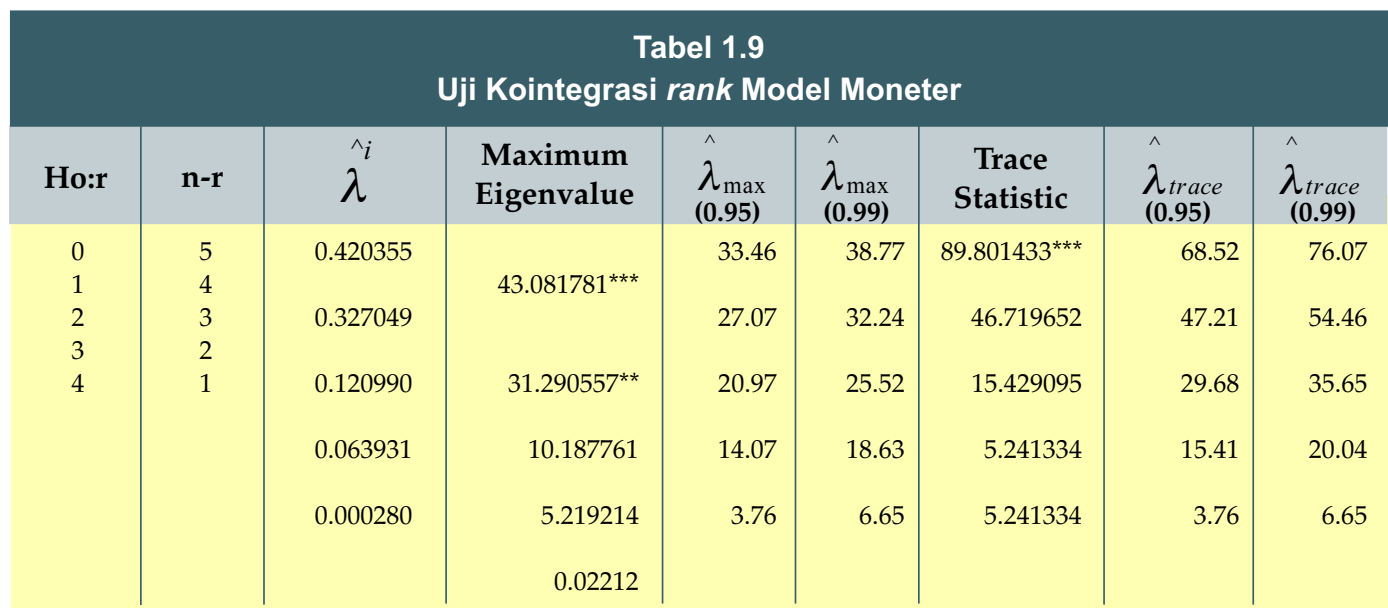

Uji rank dilakukan dengan membandingkan nilai maximum eigenvalue dan trace statistik dengan nilai kritis tabel yang disediakan oleh Osterwald-Lenum.

Pada model moneter, baik maximum eigenvalue (43.08) memiliki nilai yang lebih besar dibandingkan nilai tebel untuk $r=1$, sementara trace statistic (89.80) pada tingkat signifikansi $99 \%$ lebih besar dari nilai tabel untuk $r=0$. Ini menunjukkan terdapat 1 vektor kointegrasi pada model moneter, atau paling tidak terdapat 1 kombinasi linier independen dari variabelvariabel.

Namun demikian hal yang sebaliknya terjadi pada model neraca pembayaran, di mana tidak menunjukkan adanya kombinasi linier antara-antara variabel di dalam model.

Permasalahan pada uji Johansen muncul ketika jumlah observasi relatif kecil, di mana dalam situasi tersebut prosedur Johansen cenderung menolak hipotesis nol meskipun sebenarnya hipotesis nol adalah benar. Untuk menghindari masalah tersebut 
maka dilakukan koreksi Reimer (Reimers correction) melalui penyesuaian degreee of freedom menjadi $(T-n k)$. Hasil perhitungan Reimers correction berturut-turut ditunjukkan dalam tabel di bawah ini.

\begin{tabular}{|c|c|c|c|c|c|c|c|c|}
\hline \multicolumn{9}{|c|}{$\begin{array}{c}\text { Tabel } 1.10 \\
\text { Uji Kointegrasi rank model neraca pembayaran, Reimers correction }\end{array}$} \\
\hline Ho:r & n-r & $\hat{\lambda}_{i}$ & $\begin{array}{l}\text { Maximum } \\
\text { Eigenvalue }\end{array}$ & $\begin{array}{l}\hat{\lambda_{\max }} \\
(0.95)\end{array}$ & $\begin{array}{l}\hat{\lambda_{\max }} \\
(0.99)\end{array}$ & $\begin{array}{l}\text { Trace } \\
\text { Statistic }\end{array}$ & $\begin{array}{l}\wedge \\
\lambda_{\text {trace }} \\
(\mathbf{0 . 9 5 )}\end{array}$ & $\lambda_{\text {trace }}$ \\
\hline \multirow{6}{*}{$\begin{array}{l}0 \\
1 \\
2 \\
3\end{array}$} & 4 & 0.250806 & 18.191691 & 27.07 & 32.24 & 35.738955 & 47.21 & 54.46 \\
\hline & 3 & & & & & & & \\
\hline & 2 & 0.229312 & 16.409736 & 20.97 & 25.52 & 17.547264 & 29.68 & 35.65 \\
\hline & 1 & & & & & & & \\
\hline & & 0.011819 & 0.749007 & 14.07 & 18.63 & 1.137528 & 15.41 & 20.04 \\
\hline & & 0.006148 & 0.388521 & 3.76 & 6.65 & 0.388521 & 3.76 & 6.65 \\
\hline
\end{tabular}

Keterangan: Test assumption:Linier deterministic trend in the data

\begin{tabular}{|c|c|c|c|c|c|c|c|c|}
\hline Ho:r & n-r & $\hat{\wedge}_{i}$ & $\begin{array}{l}\text { Maximum } \\
\text { Eigenvalue }\end{array}$ & $\hat{\lambda}_{\max }^{\wedge}$ & $\hat{\lambda}_{\max }$ & $\begin{array}{c}\text { Trace } \\
\text { Statistic }\end{array}$ & $\hat{\lambda}_{\text {trace }}^{\wedge}$ & $\hat{\lambda}_{\text {trace }}^{\wedge}$ \\
\hline 0 & 5 & 0.420355 & 32.175001 & 33.46 & 38.77 & 67.066893 & 68.52 & 76.07 \\
\hline 1 & 4 & & & & & & & \\
\hline 2 & 3 & 0.327049 & 23.368897 & 27.07 & 32.24 & 34.891892 & 47.21 & 54.46 \\
\hline 3 & 2 & & & & & & & \\
\hline \multirow[t]{3}{*}{4} & 1 & 0.120990 & 7.608581 & 20.97 & 25.52 & 11.522995 & 29.68 & 35.65 \\
\hline & & 0.063931 & 3.897894 & 14.07 & 18.63 & 3.914414 & 15.41 & 20.04 \\
\hline & & 0.000280 & 0.01652 & 3.76 & 6.65 & 0.01652 & 3.76 & 6.65 \\
\hline
\end{tabular}

Setelah dilakukan koreksi Reimers, hasilnya terlihat bahwa kedua model tidak menolak hipotesis nol $(r=0)$ pada derajat signifikansi yang ditentukan. Sehingga berdasarkan hasil koreksi Reimers dapat dikatakan bahwa tidak terdapat adanya satu vektor kointegrasi pada variabel-variabel di dalam model neraca pembayaran maupun model moneter.

Tahap selanjutnya dalam prosedur Johansen adalah menentukan apakah komponen trend dan intercept terkandung di dalam model. Johansen menyarankan untuk menguji joint hypothesis, baik terhadap rank maupun komponen deterministik, hal ini selanjutnya disebut sebagai prinsip Pantula (Pantula principle). Dengan demikian estimasi kointegrasi dilakukan dengan menentukan terlebih dahulu restriksi dari model, yakni apakah data 
mengandung linier trend atau tidak, atau non-quadratic trend pada level. Hasil uji joint hypothesis (Pantula principle) ditampilkan dalam Tabel sebagai berikut:

\begin{tabular}{|c|c|c|c|c|c|}
\hline Но & $\mathbf{r}$ & $\mathbf{n}-\mathbf{r}$ & Model 2 & Model 3 & Model 4 \\
\hline$\lambda_{\max }$ test & $\begin{array}{l}0 \\
1 \\
2 \\
3\end{array}$ & $\begin{array}{l}4 \\
3 \\
2 \\
1\end{array}$ & $\begin{array}{r}24.209076 \\
20.627374 \\
9.312046 \\
0.837321\end{array}$ & $\begin{array}{r}22.811803 \\
20.577288 \\
0.939231 \\
0.487193\end{array}$ & $\begin{array}{r}26.509556 \\
21.913731 \\
13.892308 \\
0.856755\end{array}$ \\
\hline Trace test & $\begin{array}{l}0 \\
1 \\
2 \\
3\end{array}$ & $\begin{array}{l}4 \\
3 \\
2 \\
1\end{array}$ & $\begin{array}{r}54.985817^{* *} \\
30.776741 \\
10.149367 \\
0.837321\end{array}$ & $\begin{array}{r}44.815515 \\
22.003712 \\
1.426424 \\
0.487193\end{array}$ & $\begin{array}{r}63.17235^{* *} \\
36.662794 \\
14.749063 \\
0.856755\end{array}$ \\
\hline
\end{tabular}

\begin{tabular}{|c|c|c|c|c|c|}
\hline Но & $\mathbf{r}$ & $n-r$ & Model 2 & Model 3 & Model 4 \\
\hline$\lambda_{\max }$ test & $\begin{array}{l}0 \\
1 \\
2 \\
3 \\
4\end{array}$ & $\begin{array}{l}5 \\
4 \\
3 \\
2 \\
1\end{array}$ & $\begin{array}{r}43.215054^{* * *} \\
31.529532^{* *} \\
15.202839 \\
5.985593 \\
2.285786\end{array}$ & $\begin{array}{r}43.081781^{* * *} \\
31.290557^{* *} \\
10.187761 \\
5.219214 \\
0.02212\end{array}$ & $\begin{array}{r}50.069884^{* * *} \\
36.51775^{* *} \\
17.449283 \\
8.626089 \\
1.456918\end{array}$ \\
\hline Trace test & $\begin{array}{l}0 \\
1 \\
2 \\
3 \\
4\end{array}$ & $\begin{array}{l}5 \\
4 \\
3 \\
2 \\
1\end{array}$ & $\begin{array}{r}98.218804^{* * *} \\
55.00375^{* *} \\
23.474218 \\
8.271379 \\
2.285786\end{array}$ & $\begin{array}{r}89.801433^{* * *} \\
46.719652 \\
15.429095 \\
5.241334 \\
5.241334\end{array}$ & $\begin{array}{r}114.119924^{* * *} \\
64.05004^{* *} \\
27.53229 \\
10.083007 \\
1.456918\end{array}$ \\
\hline
\end{tabular}

Keterangan: ${ }^{* * *},{ }^{* *}$ masing-masing menunjukkan signifikansi pada tingkat $1 \%$ dan $5 \%$ 
Dari hasil estimasi model 2 - 4 pada Tabel 1.10 (yakni dari model yang paling restrictive) dan kemudian dengan mengaplikasikan prinsip Pantula, dapat disimpulkan bahwa menerima model 3, yakni menolak hipotesis nol pada rank $=1$, berarti tidak terdapat satu vektor kointegrasi dan tidak terdapat komponen deterministik trend pada data level. Sedangkan pada Tabel 1.11 (Model Moneter) dapat disimpulkan bahwa model 3 tidak menolak hipotesis nol pada rank $=1$, berarti terdapat satu vektor kointegrasi dan tidak terdapat komponen deterministik trend pada data level.

\section{IV.4. Estimasi Model Error Correction (EG-ECM)}

Berdasarkan hasil pengujian, pada persamaan jangka panjang tahap awal, kedua persamaan jangka panjang yang dihasilkan cenderung tidak stabil, tidak stasioner, dan cenderung memiliki pola tertentu dalam beberapa periode tertentu. Estimasi jangka pendek pada kedua model (neraca pembayaran dan moneter) yang dilakukan dengan menggunakan metode general to specific menunjukkan bahwa banyaknya lag maksimum yang dapat dimasukkan ke dalam model adalah 8. Kemudian dilakukan reduksi mulai dari lag terpanjang dengan mengaplikasikan uji general F-testing, sehingga didapatkan hasil estimasi yang paling sederhana (parsimonious regression) (lihat Gujarati, 2003, Harris, 1995).

Uji general-F menunjukkan bahwa bentuk model dinamis baik pada model neraca pembayaran maupun model moneter tidak menghendaki jumlah lag yang terlalu panjang, hal tersebut terlihat dari uji F-statitik yang tidak menolak hipotesis nol atau menerima unconstrained regression (model 5) sebagai model jangka pendek dan sekaligus sebagai hasil estimasi yang paling sederhana. Selanjutnya dari model (5) (model neraca pembayaran dan moneter) dilakukan reduksi terhadap parameter-parameter yang tidak signifikan dengan mengaplikasikan uji redundant coefficient sehingga didapatkan estimasi yang paling sederhana. Berikut ini adalah hasil estimasi EG-ECM kedua model : 
Tabel 1.14

Hasil Estimasi Jangka Pendek Model Neraca Pembayaran

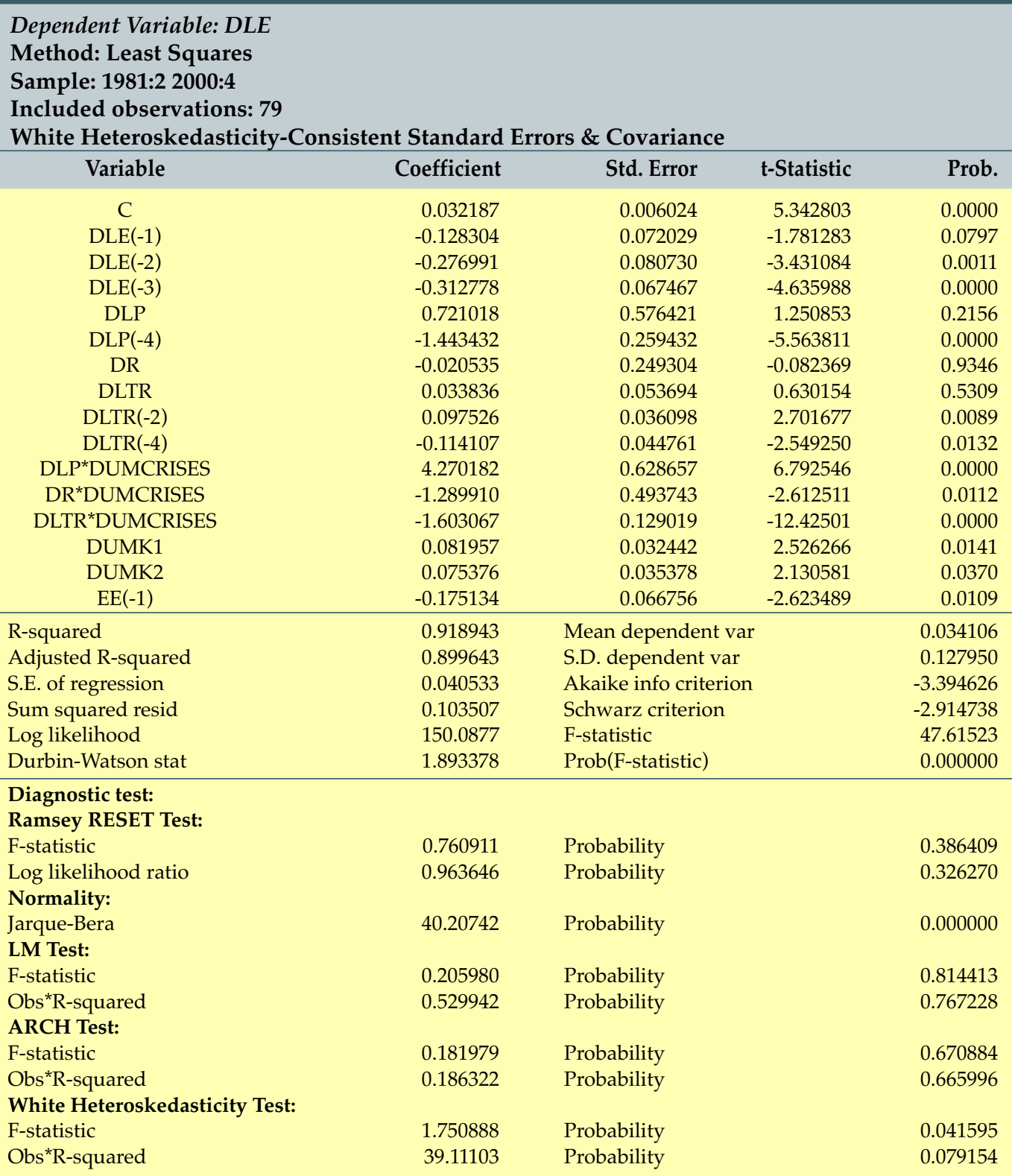

Keterangan: ${ }^{* * *},{ }^{* *},{ }^{*}$ masing-masing menunjukkan signifikansi pada tingkat $1 \%, 5 \%$ dan $10 \%$ 
Tabel 1.15

Hasil Estimasi Jangka Pendek Model Moneter

\section{Dependent Variable: DLE}

Method: Least Squares

Sample(adjusted): 1981:2 2000:4

Included observations: $\mathbf{7 9}$ after adjusting endpoints

\begin{tabular}{|c|c|c|c|c|}
\hline Variable & Coefficient & Std. Error & t-Statistic & Prob. \\
\hline $\mathrm{C}$ & 0.016453 & 0.018032 & 0.912403 & 0.3650 \\
\hline DLE(-1) & -0.291771 & 0.091611 & -3.184889 & 0.0022 \\
\hline DLE(-3) & -0.471265 & 0.070152 & -6.717762 & 0.0000 \\
\hline DLP & 1.483285 & 0.351438 & 4.220623 & 0.0001 \\
\hline DLP(-4) & -1.334569 & 0.304626 & -4.381000 & 0.0000 \\
\hline $\mathrm{DR}$ & 0.138059 & 0.333596 & 0.413849 & 0.6804 \\
\hline DR(-4) & -0.555981 & 0.241770 & -2.299625 & 0.0247 \\
\hline DLM & 0.094031 & 0.167964 & 0.559831 & 0.5775 \\
\hline DLM(-2) & -0.501888 & 0.175797 & -2.854928 & 0.0058 \\
\hline DLY & -0.450018 & 0.462510 & -0.972991 & 0.3342 \\
\hline $\operatorname{DLY}(-4)$ & 1.231251 & 0.350146 & 3.516390 & 0.0008 \\
\hline DLY*DUMCRISES & 3.718376 & 0.618613 & 6.010827 & 0.0000 \\
\hline DUMK1 & 0.131167 & 0.036682 & 3.575789 & 0.0007 \\
\hline DUMK2 & 0.087976 & 0.025964 & 3.388377 & 0.0012 \\
\hline EM(-1) & -0.124723 & 0.064394 & -1.936871 & 0.0572 \\
\hline R-squared & 0.813756 & \multicolumn{2}{|c|}{ Mean dependent var } & 0.034106 \\
\hline Adjusted R-squared & 0.773016 & \multicolumn{2}{|l|}{ S.D. dependent var } & 0.127950 \\
\hline S.E. of regression & 0.060959 & \multicolumn{2}{|l|}{ Akaike info criterion } & -2.588043 \\
\hline Sum squared resid & 0.237825 & \multicolumn{2}{|l|}{ Schwarz criterion } & -2.138148 \\
\hline Log likelihood & 117.2277 & \multicolumn{2}{|l|}{ F-statistic } & 19.97401 \\
\hline Durbin-Watson stat & 2.064148 & \multicolumn{2}{|l|}{ Prob(F-statistic) } & 0.000000 \\
\hline \multicolumn{5}{|l|}{ Diagnostic test: } \\
\hline \multicolumn{5}{|l|}{ Ramsey RESET Test: } \\
\hline F-statistic & 4.638339 & Probability & & 0.035099 \\
\hline Log likelihood ratio & 5.612179 & Probability & & 0.017836 \\
\hline \multicolumn{5}{|l|}{ Normality: } \\
\hline Jarque-Bera & 60.49603 & Probability & & 0.000000 \\
\hline \multicolumn{5}{|l|}{ LM Test: } \\
\hline F-statistic & 0.186735 & Probability & & 0.667124 \\
\hline Obs*R-squared & 0.233467 & Probability & & 0.628965 \\
\hline \multicolumn{5}{|l|}{ ARCH Test: } \\
\hline F-statistic & 0.089856 & Probability & & 0.765178 \\
\hline Obs*R-squared & 0.092112 & Probability & & 0.761509 \\
\hline \multicolumn{5}{|c|}{ White Heteroskedasticity Test: } \\
\hline F-statistic & 2.129888 & Probability & & 0.010202 \\
\hline Obs ${ }^{*} \mathrm{R}$-squared & 40.74230 & Probability & & 0.032937 \\
\hline
\end{tabular}

Keterangan: ${ }^{* * *},{ }^{* *},{ }^{*}$ masing-masing menunjukkan signifikansi pada tingkat $1 \%, 5 \%$ dan $10 \%$ 
Terhadap hasil estimasi pada kedua model, selanjutnya dilakukan uji diagnosis untuk mengetahui apakah terjadi penyimpangan asumsi klasik. Uji linieritas dilakukan dengan uji Ramsey's RESET, hasilnya menunjukkan bahwa estimasi pada kedua model cukup stabil atau menolak hipotesis nonlinier. Hasil uji diagnosis yang lain menunjukkan bahwa hasil estimasi jangka pendek model neraca pembayaran dan moneter mengindikasikan tidak adanya gejala autokorelasi, heteroskedastisitas dan residualnya berdistribusi normal. Namun demikian pada kedua model residualnya tidak berdistribusi normal. Penyimpangan dari asumsi ini dapat diabaikan sebab meskipun terjadi pelanggaran terhadap asumsi normalitas, sepanjang asumsi non-multikolinieritas, non-autokorelasi, dan homoskedastisitas terpenuhi, hasil estimasi tetap bersifat BLUE (best linier unbiased estimator) (Gujarati,2003). Selain itu Greene (1999) juga menyatakan bahwa distribusi $t$ dan $F$ pada residual yang tidak memenuhi asumsi normalitas mempunyai nilai yang mendekati distribusi $t$ dan $F$ pada residual yang memenuhi asumsi normalitas. Untuk menghindari kesalahan tipe I (type / error), Greene kemudian menyarankan agar tetap menggunakan distribusi $t$ dan $F$ yang baku meskipun residualnya menyimpang dari asumsi normalitas.

\section{IV.5. Model Neraca Pembayaran}

Pada model neraca pembayaran (Tabel 3.15) koefisien error correction term sebesar $-0,17513$ menunjukkan bahwa kecepatan penyesuaian (speed of adjusment) nilai tukar menuju ke kondisi keseimbangan adalah 17,51 persen per kuartal. Terjadinva perubahan-perubahan variabel ekonomi yang mempengaruhi nilai tukar dalam jangka pendek menunjukkan bahwa dampak dari perubahan variabel-variabel dalam mempengaruhi nilai tukar memerlukan waktu atau proses penyesuaian dari kondisi ketidakseimbangan menuju ke keseimbangan tersebut memerlukan koreksi antarwaktu.

Dampak perubahan nilai tukar terhadap nilai tukar itu sendiri terjadi relatif cepat yaitu satu kuartal. Variabel kurs satu kuartal sebelumnya memberikan tekanan negatif terhadap kurs saat ini sebesar $-0,1283$. Variabel perbedaan harga (DLP) juga memperlihatkan arah yang sesuai dengan yang diharapkan dalam memberikan pengaruh positif terhadap kurs. Namun demikian DLP(-4) memberikan pengaruh yang sebaliknya terhadap kurs, hal ini dapat dijelaskan dari hasil uji akar unit (unit root) dengan structural break pada variabel perbedaan harga yang menngindikasikan adanya break pada variabel ini, dan uji stabilitas parameter pada estimasi jangka panjang menyimpulkan bahwa terdapat perubahan struktural (structural change) pada masing-masing parameter dalam mempengaruhi nilai tukar atau nilai dari parameter pada model tidak memiliki arah yang sama untuk setiap periode. Hal 
yang sama juga terjadi pada variabel cadangan internasional (DLTR) di mana konsistensi hipotesis dipenuhi pada empat kuartal sebelumnya $(\operatorname{DLTR}(-4))^{2}$.

Variabel perbedaan tingkat suku bunga (DR) mempunyai koefisien regresi yang bernilai negatif, sesuai dengan yang diharapkan. Sehingga dalam hal ini hipotesis Keynesian di mana tingginya perbedaan tingkat suku bunga akan menyebabkan aliran modal masuk dengan disertai apresiasi mata uang domestik berlaku.

Adapun dampak kebijakan devaluasi tahun 1983 dan 1986 masing-masing sebesar 0,0819 dan 0,0753 , atau memberikan tekanan depresiasi sebesar 8,19 persen dan 7,5 persen. Lebih lanjut, dampak krisis terhadap kurs, berjalan melalui variabel-variabel harga, tingkat suku bunga dan cadangan internasioanl. Pada masa krisis konsistensi arah hubungan variabel-variabel dalam mempengaruhi nilai tukar terpenuhi, dengan koefisien estimasi yang relatif besar. Variabel perbedaan harga pada masa krisis memiliki koefisien sebesar 4,270, artinya dampak peningkatan harga domestik memberikan tekanan depresiasi terhadap kurs sebesar 427 persen. Tingginya tingkat harga domestik pada masa krisis disebabkan oleh tingginya ekspektasi inflasi yang diakselerasi olah melemahnya nilai tukar dan implementasi kebijakan pemerintah di bidang harga dan pendapatan.

Koefisien perbedaan tingkat suku bunga pada masa krisis sebesar -1,2899, berarti bahwa peningkatan perbedaan tingkat suku bunga memberikan tekanan negatif (apresiasi) mata uang domestik sebesar 128 persen. Peningkatan perbedaan tingkat suku bunga utamanya disebabkan oleh peningkatan suku bunga domestik sebagai salah satu bentuk kebijakan Bank Indonesia pada masa krisis yang ditujukan untuk mengantisipasi kegiatan spekulasi dan penyelamatan aset (flight to safety) disamping untuk menarik aliran modal masuk.

Variabel cadangan internasioanal (DLTR) pada masa krisis memiliki koefisien elastisitas sebesar -1,6030 dan tandanya juga konsisten dengan teori. Ketersediaan cadangan internasional terutama dalam bentuk valuta asing sangat penting, terutama dalam mengantisipasi peningkatan permintaan valuta asing yang dapat menyebabkan kelangkaan valuta asing yang berakibat pada apresiasi mata uang luar negeri terhadap mata uang domestik. Demikian halnya pada masa krisis, ketersediaan cadangan internasional sangat mendukung Bank Indonesia untuk dapat melakukan kebijakan sterilisasi/intervansi yang dimaksudkan untuk meredam fluktuasi nilai tukar yang berlebihan, dan sekaligus mempengaruhi persepsi pasar. Koefisien elastisitas cadangan internasional mengindikasikan bahwa ketersediaan cadangan internasional memberikan tekanan negatif (apresisasi) nilai tukar rupiah sebesar 160 persen.

2 Penelitian dengan model yang sama dilakukan oleh Thomas M. Fullerton \& Calderon di Mexico (2001), juga mengalami hal sama, yakni terdapat beberapa variabel yang tandanya tidak konsisten dengan teori. 


\section{IV.6. Model Moneter}

Berbeda dengan model neraca pembayaran hasil estimasi EG-ECM model moneter mendapatkan koefisien error correction term yang lebih kecil yakni $-0,1247$, berarti bahwa kecepatan penyesuaian (speed of adjusment) nilai tukar menuju ke kondisi keseimbangan adalah 12,47 persen per kuartal. Adapun dampak perubahan nilai tukar terhadap nilai tukar itu sendiri terjadi relatif cepat, yakni 1 kuartal. Variabel-variabel yang diestimasi pada umumnya memiliki tanda yang konsisten dengan teori, meskipun beberapa tidak signifikan. Hal ini terjadi pada variabel jumlah uang beredar dan pendapatan nasional. Meskipun demikian, tidak berarti kebijakan yang meliputi penyerapan terhadap ekses likuiditas rupiah di pasar melalui instrumen Operasi Pasar Terbuka tidak lagi diperlukan. Karena pada prinsipnya peningkatan dalam penawaran uang juga akan menyebabkan depresiasi mata uang domestik, tanpa berpengaruh terhadap tingkat suku bunga riil; tidak terdapat efek likuiditas jangka pendek di dalam model.

Lebih lanjut, perbedaan arah hubungan terjadi pada variabel pendapatan nasional, yaitu pendapatan nasional sebelum krisis dan pada masa krisis. Koefisien estimasi pendapatan nasional (DLY) pada masa krisis menunjukkan angka yang relatif besar, yakni 3,7183. Hal ini bisa dijelaskan bahwa peningkatan pendapatan domestik direspon dengan besarnya permintaan valuta asing pada masa krisis. Salah satu permintaan valuta asing yang cukup besar adalah untuk pembiyaan impor dan pelunasan hutang luar negeri. Pada periode krisis, diduga permintaan valuta asing untuk kebutuhan riil (genuine demand) perekonomian seperti pembiayaan impor, masih tinggi, terutama pada kebutuhan akan barang-barang modal.

Variabel perbedaan tingkat harga (DP) arahnya konsisten dengan teori, berarti mendukung keberlakuan hipotesis paritas daya beli (PPP), di mana kenaikan pada tingkat perbedaan harga sebesar 1 persen (cateris paribus) akan mengakibatkan nilai tukar domestik terdepreiasi 148 persen. Sama halnya dengan model neraca pembayaran, variabel kebijakan devaluasi (DUMK1 dan DUMK2) juga memberikan tekanan posistif (depresiasi) sebesar masing-masing 13 persen dan 8,7 persen.

\section{KESIMPULAN DAN SARAN}

\section{V.1 Kesimpulan}

Hasil uji akar unit menunjukkan bahwa semua variabel yang digunakan dalam model $I(1)$, kecuali perbedaan tingkat suku bunga $(R)$ yang stasioner pada level atau $I(0)$ dan first difference atau I(1). Dengan kata lain pada dasarnya data yang digunakan pada level 
mengandung akar unit, namun mampu stasioner pada first difference. Hasil uji akar unit dengan structural break dilakukan dengan mengaplikasikan metode recursive, rolling, mean shift dan trend shift. Pada metode recursive memperlihatkan bahwa terdapat break pada variabel selisih jumlah uang beredar (M2), terjadi pada tahun 1990 kuartal tiga. Metode rolling menghasilkan informasi, yakni break terjadi pada variabel perbedaan tingkat harga (CPI) yang diduga terjadi pada tahun 1986 kuartal dua. Metode sequence F-statistik yang dihitung dengan metode mean shift dan trend shift menginformasikan adanya break pada variabel total reserve (TR).

Uji kointegrasi dilakukan dalam kerangka analisis vector autoregressive (VAR) dan model jangka pendek error correction model (EG-ECM). Uji kointegrasi yang dilakukan dengan uji kointegrasi ADF menunjukkan bahwa variabel-variabel yang dipilih pada kedua model saling berkointegrasi, atau mempunyai hubungan keseimbangan jangka panjang. Uji kointegrasi Johansen (devaluasi dan krisis sebagai variabel eksogen) pada model moneter menunjukkan adanya vektor kointegrasi diantara variabel-variabel model tersebut, tetapi pada model neraca pembayaran tidak menunjukkan adanya vektor kointegrasi. Namun demikian, setelah dilakukan koreksi Reimers (Reimers correction) tidak ditemukan adanya vektor kointegrasi antarvariabel pada kedua model.

Hasil penelitian selanjutnya menunjukkan adanya hubungan antara variabel-variabel yang dipilih dalam mempengaruhi nilai tukar, baik dalam model neraca pembayaran maupun model moneter. Secara umum variabel-variabel yang digunakan menunjukkan koefisien regresi dengan arah yang sesuai harapan teori, atau kesesuaian hipotesis pada model neraca pembayaran dan model moneter terpenuhi. Namun, variabel cadangan internasional (DLTR) dan pendapatan nasional (DLY) mengalami perbedaan arah hubungan antara pada masa sebelum dan masa krisis. Pada masa sebelum krisis variabel cadangan internasional (DLTR) menunjukkan arah yang tidak konsisten dengan teori dan berubah arah pada masa krisis, sedangkan variabel pendapatan nasional (DLY) menunjukkan arah hubungan yang konsisten dengan teori pada masa sebelum krisis dan berubah arah pada masa krisis.

Selanjutnya hasil estimasi EG-ECM pada kedua model mengindikasikan bahwa dampak dari perubahan variabel-variabel dalam mempengaruhi nilai tukar memerlukan waktu atau proses penyesuaian dari kondisi ketidakseimbangan menuju ke keseimbangan memerlukan koreksi antar waktu. Pada model neraca pembayaran diperoleh kecepatan penyesuaian (speed of adjustment) menuju keseimbangan yang lebih besar dari model moneter. Kecepatan penyesuaian pada model neraca pembayaran sebesar 17,51 persen dan model moneter sebesar 12,47 persen per kuartal. Hasil estimasi juga menunjukkan adanya konsistensi variabel perbedaan harga yang diproksi dengan costumer price index 
(DLP) dalam mempengaruhi nilai tukar. Perbedaan harga saat ini berdampak langsung terhadap nilai tukar, tetapi karena adanya break pada variabel DLP sehingga terjadi perubahan arah pada tingkat harga sebelumnya DLP (-1) dalam estimasi.

Konsistensi yang lain dipenuhi oleh variabel perbedaan jumlah uang beredar (DLM) dan perbedaan pendapatan nasional (DLY). Variabel tingkat suku bunga menunjukkan arah yang berbeda pada kedua model, pada model neraca pembayaran tingkat suku bunga memberikan tekanan negatif terhadap nilai tukar dan pada model moneter sebaliknya. Hal ini dapat dijelaskan karena tingginya perbedaan tingkat suku bunga akan menyebabkan aliran modal masuk dengan disertai apresiasi mata uang domestik berlaku. Di sisi lain suku bunga domestik yang tinggi sering mencerminkan tingginya harapan inflasi di negara tersebut, karena itu mengakibatkan depresiasi mata uang domestik

Perbedaan arah hubungan juga terjadi pada variabel perbedaan pendapatan nasional (DLY), di mana pada masa krisis pendapatan nasional memberikan tekanan positif (depresiasi) mata uang domestik. Lebih lanjut, variabel dummy kebijakan (devaluasi) seperti dihipotesakan sebelumnya berdampak positif (depresiasi) terhadap nilai tukar terbukti. Variabel krisis (DUMCRISES) berpengaruh terhadap nilai tukar melalui variabel-variabel yang diestimasi di dalam model.

\section{V.2. Saran}

1. Mengupayakan konsistensi kebijakan harga untuk mengantisipasi tekanan terhadap nilai tukar domestik. Upaya mencapai kestabilan harga dapat dilakukan dengan menetapkan sasaran inflasi IHK yang dipandang cukup realistis dan sesuai dengan kondisi perekonomian.

2. Mengantisipasi timbulnya goncangan (syok) dari variabel-variabel fundamental ekonomi yang ternyata berpengaruh terhadap nilai tukar. Hal ini dapat dilakukan terutama terhadap variabel-variabel yang sifatnya dapat langsung dikontrol oleh pemerintah, seperti kebutuhan impor dan kebutuhan untuk pelunasan hutang.

3. Pada masa krisis ketersediaan cadangan internasional memberikan tekanan negatif terhadap nilai tukar, maka kebijakan menambah pasokan valuta asing melalui sterilisasi valuta asing sangat diperlukan.

4. Kebijakan stabilisasi nilai tukar rupiah juga harus didukung oleh upaya pengawasan terhadap tingkat kepatuhan bank dalam transaksi valuta asing, tentang pembatasan terhadap transaksi rupiah dan pemberian kredit valuta asing oleh bank dan upaya membatasi kegiatan spekulasi. 


\section{Referensi}
.........,"Eviews 4.0 User's Guide", Quabtitative Micro Software, LLC, 2000
.........., "Short Term Forecast Model of Indonesian Economy; SOFIE", Bank Indonesia.
.........., Laporan Tahunan Bank Indonesia 2001
Laporan Tahunan Bank Indonesia 2002

Alan L.Tucker, "International Financial Markets",Temple University, West Publishing Company-West New York.

Bilson,J.,and R.Martston (eds.),"Exchange Rate Theory and Practice",Chicago: The University of Chicago Press, 1984.

Closterman, Jorg and Schnatz, Bernd, "The Determinants of The Euro-Dollar Exchange Rate: synthetic fundamentals and a non-existing currency", Economic Research Group of Deutchebank, May 2000.

De Grauwe.P.,"International Money Postwar Trends and Theories", Second Edition, Oxford University Press, 1996.

Dickinson D.G \& William A.Allan., "Monetary policy, Capital Flows and Exchange Rates,Essay in Honour of Maxwell Fry", Routledge International Studies in Money and Banking, 2002.

Edwards, S, "Real Exchange Rates, Devaluation, and Adjustment", Cambridge, MA: MIT Press, 1991.

Edwards, Sebastian,"The Determinants of The Choice Between Fixed And Flexible Exchange-Rate Regimes", NBER Working Paper, September 1996.

Elbadawi,I.E."Estimating Long-Run Equlibrium Real Exchange Rates," in J.Williamson ,ed., Estimating Long-Run Equlibrium Real Exchange Rates, Washington,DC:Institute for International Economics, 1994.

Enders.W, “Applied Economtric Time Series”, John Wiley \& Sons,INC, 1995.

Engle R.F \& C.W.J.Granger, "Long-Run Economic Relationship", Reading in Cointegration, Oxford University, 1995. 
Fritsche,Charmaine P., and Myles S.Wallace 1997,"Forecasting the Exchange Rate: PPP Versus a Random Walk," Economics Letters 54:pp.69-74.

Fullerton M.Thomas, Jr.Miwa Hattori and Cuauhtemoc Caldera,"Error Correction Exchange Rate Modelling: Evidence for Mexico," Journal of Economics And Finance, Vol.25, Number 3, Fall 2001,pp.358-368.

Frenkel J.A \& Harry G.Johnson, "The Economics of Exchange Rates: Selected Studies", Addison Wesley Publishing Company, 1978.

Garry Koop, “Analysis of Economic Data”, John Wiley \& Sons, LTD, 2000.

Grubacic Sanja,"Real Exchange Rate Determination in Eastern Europe",AEJ: Vol.28, No.3, September 2000,pp.346-363.

Harris, R.I.D., "Using Cointegration Analysis In Econometric Modelling”, Prentice Hall/ Hervester Wheatsheat, 1995.

Hervey, John.T, “Exchange Rate Theory and The Fundamentals", Journal of Post Keynesian Economics, Vol.24, No.1-3, Fall 2001.

Hendry David,F, “Dynamic Econometrics”, Oxford University Press, 1995.

Hill, Hall, “Ekonomi Indonesia”, Edisi Kedua, PT RajaGrafindo Persada, Jakarta 2001.

Iljas, Achjar, "Menuju Kestabilan Nilai Rupiah Melalui Independensi, Akuntabilitas dan Transparansi”, Makalah Diskusi Panel Kemandirian Bank Indonesia Pasca UU No.23 Tahun 1999, Jakarta 1999.

Insukindro, "Sindrum R² Dalam Analisis Regresi Runtun Waktu", Jurnal Ekonomi dan Bisnis Indonesia, Vol.13, No.4, 1- 11, Universitas Gadjah Mada, 1998.

Insukindro, "Pemilihan Model Ekonomi Empirik dengan Pendekatan Model Koreksi Kesalahan”, Journal Ekonomi dan Bisnis Indonesia, Vol.14, No.1. 1-8, Universitas Gadjah Mada, 1999.

Johansen.S, "Likelihood-Based Inference In Cointegrated Vector Autoregressive Models", Oxford University Press, 1995.

Jones,R.W \& Kenen,P.B, "Handbook of International Economics", Vol.II, Elsevier Science Publisher B.V, 1985.

Kim, Benjamin J.C., and Soowon Mo.1995."Cointegration and the Long Run Forecast of Exchange Rates," Economics Lettres, Vol.48, pp.353-359. 
Kim, Yoonbai, "Purchasing Power Parity in The Long Run: A Cointegration Approach", Journal of Money, Credit, and Banking, Vol.22,No.4, November 1990.

Kulkarni, Kishore, "Determination of Chinse Yuan Rate: An Analysis of Foreign Exchange Transactions”, Apllied Bussiness Research, Colorado May 1999.

Kuncoro, Mudrajat, "Metode Kuantitatif; Teori dan Aplikasi Untuk Bisnis dan Ekonomi”, Macmillan Education LTD, 1990.

Llewellyn D.T \& Chris Milner, "Current Issues In International Monetary Economics", Macmillan Education LTD, 1990.

MacDonald, Ronald (1995), "Long Run Exchange Rate Modeling: A Survey of the Recent Evidence", IMF Staff Papers 42:437-489.

MacDonald, R. and M.P. Taylor (1992), "Exchange Rate Economics: A Survey”, IMF Staff Papers, vol.39, no.1

Maddala G.S \& In-Moo Kim, "Unit Roots Cointegration and Structural Change", Cambridge University Press, 1998.

Maurice D.Levi, "International Finance: The Markets and Financial Management of Multinational Business", Third Edition-McGraw-Hill, Inc-1996.

McKnown, Robert, and Myles S.Wallace,1994. "Cointegration Tests of The Monetary Exchange Rate Model For Three High-Inflation Economics," Journal of Money, Credit, and Banking Vol.26, pp.396-411.

Melvin M,"International Money \& Finance", HarperCollins, 1995.

Modeste, Nelson C., and Muhammad Mustafa,1999,"An Error-Correction Model of the Demand for Equity Mutual Funds in the U.S. 1973-1994" Journal of Economics And Finance, Vol.23: pp.39-44.

Noussair, Charles.N, Plott Charles.R and Reizman, Raymond.G, "The Principles of Exchange Rate Determination in an International Finance Experiment", Journal of Political Economy, Vol.105, No.4, 1997.

Paul de Grauwe, "International Money: Postwar Trends and Theories", The University of British Columbia, Second Edition, Oxford University Press, Oxford 1996.

Pindyck, Robert S., and Daniel L.Rubinfeld 1998,"Econometric Models And Economics Forecast," Fourth Edition, Irwin McGraw-Hill: Boston, MA. 
Rogoff, Kenneth.1996, "The Purchasing Power Parity Puzzle," Journal of Economic Literature, Vol.34, pp.647-668.

Sach, Jeffrey D, "Economic Transition and The Economic Regime”, AEA Papers and Proceedings, May 1996.

Sarno, Lucio and Mark P.Taylor. 2002, "Purchasing Power Parity and the Real Exchange Rate", IMF Staff Papers, vol.49, no.1, pp.65-105.

Thomas, R.L. 1993, "Introductory Econometrics", Second Edition, Longman Publishing, New York.

Visser, Hans., "A Guide to International Monetary Economics”, Second Edition, Edwar Elgar Publishing Limited, USA.

Wang Peiji., "Financial Econometrics, Method and Models", Routledge Taylor \& Francis Group, 2003.

Warjiyo, Perry and Agung, Juda, "Transmission Mechanisms of Monetary Policy In Indonesia", Directirate of Economic Research and Monetary Policy Bank Indonesia, July 2002. 